\title{
Platelet-Rich Fibrin in Coverage of Gingival Recession: A Systematic Review and Meta-Analysis
}

\author{
Miguel Augusto Riquelme Rodas ${ }^{1}$ Bruna Luísa de Paula ${ }^{1}$ Victor Fabrizio Cabrera Pazmiño ${ }^{2}$ \\ Flávia Ferraz dos Santos Lot Vieira $\quad$ Joel Ferreira Santiago Junior ${ }^{1} \quad$ Elcia Maria Varize Silveira ${ }^{1}$
}

\author{
${ }^{1}$ Universidade do Sagrado Coração (USC), Bauru, São Paulo, Brazil \\ 2Department of prosthesis, Hospital for Rehabilitation of \\ Craniofacial Anomalies (HRAC), University of São Paulo (USP), \\ Bauru, São Paulo, Brazil
}

Eur J Dent 2020;14:315-326

\begin{abstract}
Address for correspondence Elcia Maria Varize Silveira, PhD, MSc, DDS, Universidade do Sagrado Coração Bauru, Irmã Arminda,10-50, Jardim Brasil, Bauru, São Paulo 17011-160, Brazil (e-mail: elcia_mvs@hotmail.com).
\end{abstract}

\begin{abstract}
Keywords

- connective tissue

- platelet-rich fibrin

- gingival recession

- systematic review

This systematic review and meta-analysis sought to evaluate the efficacy of platelet-rich fibrin (PRF) membranes versus subepithelial connective tissue grafts (SCTGs) in the coverage of Miller class I and II gingival recessions. After the inclusion and exclusion criteria were applied, the quality of seven articles (Cohen's Kappa $=0.9$ ) was evaluated using the Jadad scale. The MEDLINE/PubMed, Cochrane, and Web of Science databases were consulted, and manual searches were performed in the most popular periodontics journals. The studies included considered a total of 122 patients, 203 surgical fields on which SCTGs were used, and 205 surgical fields on which PRF was used. The parameters analyzed were probing depth, clinical attachment level, gingival recession, and keratinized mucosa. The minimum follow-up period accepted was 6 months. A statistically significant difference between the SCTG and PRF groups was found only in the case of keratinized mucosa. However, gingival recession, clinical attachment level, and probing depth parameters in the PRF group were found to be statistically equal to those of the SCTG group (the gold standard) $(p \geq 0.05)$. PRF membranes were determined to be a promising alternative to autogenous gingival grafts in the treatment of Miller class I and II gingival recessions.
\end{abstract}

\section{Introduction}

Gingival recession can be defined as the apical migration of the gingival margin toward the cementoenamel junction. It leads to cosmetic complications and discomfort, since both the cementum covering the root surface and the dentin are exposed to the oral environment. ${ }^{1}$ The etiology of gingival recession is multifactorial, though the condition is typically associated with bacterial plaque buildup on the teeth.

The changes associated with the pathological migration of the gingiva go far beyond cosmetic irregularities; they may involve serious root lesions as a result of this bacterial plaque buildup. Thus, one of the main objectives of periodontal surgery is to obtain predictable root coverage..$^{1,2}$

Miller class I and II recessions are those for which the chance of clinical success is greatest and for which the most complete coverage is obtained. ${ }^{3}$ In these cases, subepithelial connective tissue grafts (SCTGs) are considered the gold standard for the functional and cosmetic predictability they provide., 4,5

The literature reports on different techniques and protocols in which SCTGs are used; these grafts may be employed alone or in combination with biomaterials. ${ }^{6}$ Though efficacy varies, the use of autogenous grafts always requires the opening of a second surgical site to remove tissue, a process which increases postoperative morbidity. SCTGs are limited in size, since the area available for donor tissue, which is typically palatal, is restricted; therefore, multiple recessions cannot be treated. ${ }^{4}$

A variety of research into substitutes for SCTGs has been performed. However, the applications of biomaterials, such as acellular dermal matrices, collagen membranes, and enamel matrix derivatives, are also limited by financial and/ or clinical restrictions. ${ }^{6}$ In the last decade, however, biomaterials produced using autogenous platelet concentrates 
have created new possibilities for tissue healing processes; most recently, they have been used as promising substitutes for SCTGs. Second-generation platelet concentrates include platelet-rich fibrin (PRF), which is a completely autogenous material available in limited quantities and prepared using small portions of the patient's own blood without the addition of anticoagulants. ${ }^{7.8}$

Recent studies have recommended the use of PRF membranes for the treatment of gingival recession as an alternative to SCTGs. ${ }^{9-17}$ However, because it is a new type of biomaterial that has not been tested in many prospective follow-up studies, issues such as root coverage predictability, effects on healing, and the molecular mechanisms of action involved in these processes have yet to be fully understood. ${ }^{12}$ These factors support this systematic review of the literature and meta-analysis, which together seek to objectively present the most recent findings on the efficacy of PRF as an alternative to the gold standard in the coverage of Miller class I and II gingival recessions. This review considers clinical periodontal parameters such as probing depth, clinical attachment level, gingival recession, and keratinized mucosa.

\section{Materials and Methods}

This systematic review/meta-analysis was recorded in the PROSPERO international prospective register of systematic reviews (National Institute for Health Research, United Kingdom) under protocol number 42017068165. According to the PRISMA (Preferred Reporting Items for Systematic Reviews and Meta-Analyses) criteria, the central question, "are PRF membranes effective as a replacement for the gold standard in the treatment of Miller class I and II gingival recessions?," was formulated based on a PICO (Population; Intervention; Comparison; Outcome) framework. In the PICO framework, the population was patients receiving Miller class I or II root coverage surgeries; the intervention was root coverage surgical technique in which a PRF membrane is used (experimental group) and a root coverage surgical procedure involving SCTGs (control group); the comparison was sites treated with PRF membranes versus sites treated with SCTGs; and the outcome was the evaluation of probing depth, clinical attachment level, gingival recession (defined as the height of the retraction from the cementoenamel junction to the free gingival margin), and keratinized mucosa (measured based on the most apical point of the free gingival margin to the mucogingival junction) through the use of a specific search strategy and inclusion and exclusion criteria, and by performing methodology screenings, extraction, synthesis, and evaluation of the previously established data.

\section{Search Strategy}

Two of this review's authors (B.L.P. and M.A.R.R.; Cohen's Kappa $=0.9$ ) performed independent searches in various online libraries and databases, including MEDLINE/ PubMed, the Cochrane Central Register of Controlled Trials, and the Web of Science Journal Search. The manual search was performed in the following journals: Journal of Clinical Periodontology, Journal of Periodontology, Periodontology
2000, Journal of Periodontal Research, Clinical Oral Implants Research, Clinical Implant Dentistry and Related Research, Clinical Oral Investigations, Oral and Maxillofacial Surgery, Journal of Dental, Journal of Dental Research, PlosOne, and Biomaterials.

The search was completed on June 4,2018. The following keywords were combined in the following ways in all of the databases and journals: "connective graft AND PRF" "connective graft AND PRF AND gingival recession," "connective graft AND PRF AND gingival recession AND randomized clinical trial," "subepithelial connective graft AND PRF AND gingival recession," and "subepithelial connective graft AND PRF AND gingival recession AND randomized clinical trial." In MeSH (Medical Subject Heading), the terms considered were "connective graft and PRF" ([MeSH Terms] AND "design" gingival recession [All Fields] OR "randomized clinical trial" subepithelial connective graft [All Fields]).

\section{Study Selection and Inclusion Criteria}

The studies selected included only articles that were published in English and which described the clinical evaluation of the use of PRF as a replacement for SCTGs in Miller class I and II root coverage procedures. The minimum follow-up period required for inclusion was 6 months. Only randomized controlled trials with at least 10 patients were used and with methodology that compared a control group (SCTG and coronally positioned flap) to an experimental group (PRF and coronally positioned flap). Clinical cases, prospective and retrospective studies, research performed on animals, studies without control groups, and studies which did not allow for proper comparisons of the parameters were excluded. The research team held meetings to decide on inconsistencies between the articles selected in the individual searches. All additional information necessary to the establishment of the articles to be used in this review was obtained through contact with the original authors. All of the titles and abstracts considered relevant were selected for a complete reading of the article and subsequent appraisal.

\section{Risk of Bias and Analysis of the Quality of the Studies Included}

The quality of the articles included in this review was evaluated using the Jadad scale, as detailed in $\boldsymbol{\sim}$ Table $1 \mathbf{0}^{18,19}$ Heterogeneity was analyzed using Cochran's $Q\left(x^{2}\right)$, in which the index of heterogeneity $\left(\mathrm{I}^{2}\right)$ was measured and found to be above $75 \%$ $(0-100)$, a result which is indicative of relevant heterogeneity. ${ }^{20}$

\section{Statistical Analysis}

The Reviewer Manager software, version 5.3 (Copenhagen: The Nordic Cochrane Centre, The Cochrane Collaboration, 2014) was used to perform the meta-analysis and produce the graphs. The analysis of the clinical parameters defined probing depth, clinical attachment level, gingival recession, and keratinized mucosa as the means and standard deviations of each group, and the weight of contribution of each study to the analyses performed was also calculated, 
Table 1 Jadad scale for quality analysis of articles used

\begin{tabular}{|l|l|l|l|l|l|l|l|l|}
\hline Quality scale-Jadad et al, 1996 & Score & $\begin{array}{l}\text { Jankovic } \\
\text { et al, } \\
\mathbf{2 0 1 2}\end{array}$ & $\begin{array}{l}\text { Eren and } \\
\text { Atilla, } \\
\mathbf{2 0 1 4}\end{array}$ & $\begin{array}{l}\text { Tunalli } \\
\text { et al, } \\
\mathbf{2 0 1 5}\end{array}$ & $\begin{array}{l}\text { Uraz } \\
\text { et al, } \\
\mathbf{2 0 1 5}\end{array}$ & $\begin{array}{l}\text { Eren } \\
\text { et al, } \\
\mathbf{2 0 1 6}\end{array}$ & $\begin{array}{l}\text { Oncü, } \\
\mathbf{2 0 1 7}\end{array}$ & $\begin{array}{l}\text { Mufti } \\
\text { et al, } \\
\mathbf{2 0 1 7}\end{array}$ \\
\hline Warameters & & 1 & 1 & 1 & 1 & 1 & 1 \\
\hline $\begin{array}{l}\text { Was the method of randomization appro- } \\
\text { priate? }\end{array}$ & $(0$ or +1$)$ & 1 & 1 & 1 & 1 & 1 & 1 \\
\hline Was the study described as double-blind? & $(0$ or +1$)$ & 0 & 0 & 0 & 0 & 0 & 0 \\
\hline $\begin{array}{l}\text { Was the method used for double-blindness } \\
\text { adequate? }\end{array}$ & $(0$ or +1$)$ & 0 & 0 & 0 & 0 & 0 & 0 \\
\hline $\begin{array}{l}\text { Was the method used to generate the } \\
\text { randomization sequence appropriate? }\end{array}$ & (0 or 1$)$ & 0 & 0 & 0 & 0 & 0 & 0 \\
\hline Was the masking method appropriate? & $(0$ or 1$)$ & 0 & 0 & 0 & 0 & 0 & 0 \\
\hline $\begin{array}{l}\text { Have the numbers and reasons for losses } \\
\text { and dropouts been described? }\end{array}$ & $(0$ or +1$)$ & 0 & 1 & 0 & 1 & 0 & 1 \\
\hline Total & & 2 & 3 & 2 & 3 & 2 & 0 \\
\hline
\end{tabular}

the significance level considered was 0.05. Details are shown in - Tables $\mathbf{2}$ and $\mathbf{3}$.

\section{Results}

A total of 706 articles were found to have the keywords considered herein. After the inclusion and exclusion criteria were applied to the titles and complete abstracts and all duplicate articles were removed, ten eligible articles remained. After these ten articles were appraised in their entirety, three were excluded and seven were selected for the qualitative and quantitative analyses (-Fig. 1). All of the articles selected were published between 2012 and 2018.

\section{Patients: Surgical Sites, PRF Protocols, and Medications}

A total of 122 patients of both sexes were evaluated. They ranged from 18 to 60 years of age and were selected based on the presence and type of gingival recession (Miller classes I and II). Patients with systemic health problems, those with periodontal health problems (plaque and bleeding index $\leq 25 \%$ ), smokers, heavy drinkers, and patients undergoing orthodontic treatment were excluded. The surgical sites were also considered: procedures were performed on both the upper jaw and the lower jaw. Two hundred and three cases represented the control group (SCTG), and 205 cases represented theexperimentalgroup(PRF).Themostfrequently employed follow-up period was 6 months in length; the follow-up period was 12 months long in only one article. ${ }^{11}$

Small differences were found in the PRF protocols used in the studies. Only one of the studies used less than $10 \mathrm{~mL}$ of blood. ${ }^{13}$ Two articles applied a centrifugation time shorter than 12 minutes. ${ }^{9.14}$ Only three teams of authors provided details on the brand and model of the centrifuge used to fabricate the membranes. ${ }^{10,11,13}$

Different research teams also prescribed different medications to patients. In the chemical control of plaque, the studies varied in the type of antiseptic solution adopted, its concentration, the duration of mouthwash rinsing recommended, and the number of days for which mouthwash was to be used before and after surgery. Variations in antibiotic, anti-inflammatory, and painkiller prescriptions and dosages were also found ( - Table 4 ).

Basic periodontal therapy prior to the surgical procedure was consistent among the studies. However, the protocols varied and included steps such as oral hygiene, scaling, and root planing, and professional dental cleaning with rubber cups and/or abrasive polymer pastes (-Table $\mathbf{5}$ ). In the postoperative period, the patients received important recommendations, including liquid or soft food diets, proper hygiene at the surgical site, and rinsing with chlorhexidine for the first 2 weeks.

\section{Clinical Periodontal Parameters}

The meta-analysis revealed no significant differences between the PRF and SCTG groups in terms of probing depth, clinical attachment level, or gingival recession.

The groups did not differ in probing depth values at the 6-month follow-up evaluation ( $p=0.28$; mean difference $[\mathrm{MD}]=0.04 \mathrm{~mm} ; 95 \%$ confidence interval $[\mathrm{Cl}]:-0.03$ to 0.11 ). The $\mathrm{I}^{2}$ was $0 \%(p=0.48 ; \boldsymbol{- F i g .}$ ). Similar data were observed at baseline, at which point there were no significant differences between the groups ( $p=0.28$; MD: $0.04 \mathrm{~mm}$; 95\% $\mathrm{CI}=-0.03$ to 0.11$)$. The $\mathrm{I}^{2}$ was $0 \%(p=0.48 ;-$ Fig. 3 ).

No significant differences were found between the groups' clinical attachment levels after 6 months of follow-up ( $p=0.90$; MD: $-0.0395 \% \mathrm{CI}:-0.55$ to 048 ). The $\mathrm{I}^{2}$ was $92 \%$ $(p<0.00001 ;-$ Fig. 4). Similarly, there were no significant differences in clinical attachment levels between the groups at baseline ( $p=0.39$; MD: $0.27 ; 95 \% \mathrm{CI}:-0.34$ to 0.87$)$. The $\mathrm{I}^{2}$ was $91 \%(p<0.00001 ;-$ Fig. 5$)$.

No significant differences were found between the groups' gingival recessions at 6 months of follow-up $(p=0.08$; MD: 0.16 ; $95 \% \mathrm{Cl}:-0.02$ to 0.33$)$. The $\mathrm{I}^{2}$ was $81 \%(p<0.0001)$. The gingival recessions also did not differ between the groups 
Table 2 General qualitative data

\begin{tabular}{|c|c|c|c|c|c|c|c|}
\hline Authors & $\begin{array}{l}\text { Jankovic et al, } \\
2012\end{array}$ & $\begin{array}{l}\text { Eren and } \\
\text { Atilla, } 2014\end{array}$ & $\begin{array}{l}\text { Tunalli et al, } \\
2015\end{array}$ & $\begin{array}{l}\text { Uraz et al, } \\
2015\end{array}$ & $\begin{array}{l}\text { Eren et al, } \\
2016\end{array}$ & Öncü, 2017 & $\begin{array}{l}\text { Mufti et al, } \\
2017\end{array}$ \\
\hline $\begin{array}{l}\text { Types of } \\
\text { study }\end{array}$ & RCT & $\mathrm{RCT}$ & $\mathrm{RCT}$ & RCT & RCT & RCT & $\mathrm{RCT}$ \\
\hline $\begin{array}{l}\text { Period } \\
\text { (mo) }\end{array}$ & 6 & 6 & 12 & 6 & 6 & 6 & 6 \\
\hline $\begin{array}{l}\text { No. } \\
\text { (patients) }\end{array}$ & 15 & 22 & 10 & 15 & 24 & 20 & 16 \\
\hline Test group & $\begin{array}{l}15 \mathrm{OA} \\
\text { (CF+PRF) }\end{array}$ & $\begin{array}{l}44 \mathrm{OA} \\
\text { (CF+PRF) }\end{array}$ & $\begin{array}{l}22 \mathrm{OA} \\
\text { (CF+PRF) }\end{array}$ & $\begin{array}{l}24 \mathrm{OA} \\
\text { (CF+PRF) }\end{array}$ & $\begin{array}{l}30 \mathrm{OA} \\
\text { (CF+PRF) }\end{array}$ & $\begin{array}{l}30 \mathrm{OA} \\
\text { (CFM+PRF) }\end{array}$ & $\begin{array}{l}16 \mathrm{OA} \\
\text { (CF+PRF) }\end{array}$ \\
\hline $\begin{array}{l}\text { Control } \\
\text { group }\end{array}$ & $\begin{array}{l}15 \mathrm{OA} \\
(\mathrm{CF}+\mathrm{SCTG})\end{array}$ & $\begin{array}{l}44 \mathrm{OA} \\
(\mathrm{CF}+\mathrm{SCTG})\end{array}$ & $\begin{array}{l}22 \mathrm{OA} \\
(\mathrm{CF}+\mathrm{SCTG})\end{array}$ & $\begin{array}{l}24 \mathrm{OA} \\
(\mathrm{CF}+\mathrm{SCTG})\end{array}$ & $\begin{array}{l}30 \mathrm{OA} \\
(\mathrm{CF}+\mathrm{SCTG})\end{array}$ & $\begin{array}{l}30 \mathrm{OA} \\
(\mathrm{CF}+\mathrm{SCTG})\end{array}$ & $\begin{array}{l}16 \mathrm{OA} \\
(\mathrm{CF}+\mathrm{SCTG})\end{array}$ \\
\hline $\operatorname{Sex}(M / F)$ & $5 \mathrm{M} / 10 \mathrm{~F}$ & $9 \mathrm{M} / 13 \mathrm{~F}$ & $4 \mathrm{M} / 6 \mathrm{~F}$ & $9 \mathrm{M} / 6 \mathrm{~F}$ & $10 \mathrm{M} / 14 \mathrm{~F}$ & $9 \mathrm{M} / 11 \mathrm{~F}$ & $9 \mathrm{M} / 7 \mathrm{~F}$ \\
\hline Age (y) & $19-47$ & $18-32$ & $25-52$ & $23-48$ & $>18$ & $20-60$ & $>18$ \\
\hline Smokers & NR & 0 & 0 & 0 & 0 & 0 & 0 \\
\hline Miller class & I-II & I-II & $I-I I$ & I-II & I-II & I-II & I-II \\
\hline $\begin{array}{l}\text { Surgical } \\
\text { sites }\end{array}$ & NR & $M / J$ & $M / J$ & $M / J$ & $\mathrm{M} / \mathrm{J}$ & $M / J$ & $M / J$ \\
\hline $\begin{array}{l}\text { Recession } \\
(\mathrm{mm})\end{array}$ & $\geq 2 \mathrm{~mm}$ & $\geq 2 \mathrm{~mm}$ & $\geq 3 \mathrm{~mm}$ & $\geq 2 \mathrm{~mm}$ & $\geq 2 \mathrm{~mm}$ & $\geq 3 \mathrm{~mm}$ & NR \\
\hline $\begin{array}{l}\text { Histologi- } \\
\text { cal analysis }\end{array}$ & NA & NA & NA & NA & NA & NA & NA \\
\hline $\begin{array}{l}\text { Molecular } \\
\text { analysis }\end{array}$ & NA & NA & NA & NA & Yes & NA & NA \\
\hline $\begin{array}{l}\text { Index of } \\
\text { plaque }\end{array}$ & Controlled & Controlled & Controlled & Controlled & Controlled & Controlled & Controlled \\
\hline $\begin{array}{l}\text { Centrifuge } \\
\text { (mark) }\end{array}$ & NR & $\begin{array}{l}\text { Nuve. Laborato- } \\
\text { ry. Eq. NF200 }\end{array}$ & $\begin{array}{l}\text { Hettich Uni- } \\
\text { versal } 320\end{array}$ & NR & NR & PC-02 Process & NR \\
\hline Caries & 0 & 0 & 0 & 0 & 0 & 0 & 0 \\
\hline $\begin{array}{l}\text { Centrif- } \\
\text { ugation } \\
\text { prot. }\end{array}$ & $\begin{array}{l}10 \mathrm{~mL} / 3,000 \\
\mathrm{RPM} / 10 \mathrm{~min}\end{array}$ & $\begin{array}{l}10 \mathrm{~mL} / 400 \mathrm{G} / 12 \\
\min \end{array}$ & $\begin{array}{l}10 \mathrm{~mL} / 2,700 \\
\mathrm{RPM} / 12 \mathrm{~min}\end{array}$ & $\begin{array}{l}10 \mathrm{~mL} / 2,700 \\
\mathrm{RPM} / 12 \mathrm{~min}\end{array}$ & $\begin{array}{l}10 \mathrm{~mL} / 2,700 \\
\mathrm{RPM} / 12 \mathrm{~min}\end{array}$ & $\begin{array}{l}9 \mathrm{~mL} / 2,700 \\
\mathrm{RPM} / 12 \mathrm{~min}\end{array}$ & $\begin{array}{l}10 \mathrm{~mL} / 3,000 \\
\mathrm{RPM} / 10 \mathrm{~min}\end{array}$ \\
\hline Pain & $<$ in PRF (d) & NR & NR & NR & NR & $<$ in PRF $(7 d)$ & $\begin{array}{l}<\text { in PRF } \\
\left(1^{\mathrm{a}}, 2^{\mathrm{a}}, 3^{\mathrm{a}} w \mathrm{w}\right)\end{array}$ \\
\hline
\end{tabular}

Abbreviations: AM, anterior maxilla; CF + PRF, coronal flap + platelet rich fibrin; CF + SCTC, coronal flap + subepithelial connective tissue graft; CFM + PRF, coronal flap modified + platelet-rich fibrin; CFM + SCTG, coronal flap modified + subepithelial connective tissue graft; HS, histological studies; M//F, male/female; M/J, maxilla/jaw; MS, molecular studies; N, number of patients; NA, not applicable; NR, not reported; OA, operated areas; RCT, randomized clinical trial.

at baseline ( $p=0.09$; MD: $0.31 ; 95 \% \mathrm{CI}:-0.05$ to 0.67$)$. The $\mathrm{I}^{2}$ was $89 \%$ ( $p<0.00001 ;$ - Figs. 6 and - Figs. 7).

At 6 months of follow-up, the groups differed significantly only in their keratinized mucosa values $(p<0.00001$; MD: -0.39 95\% CI: -0.56 to 0.22$)$. The $\mathrm{I}^{2}$ was $21 \%(p=0.27$;

-Fig. 8). However, these values did not differ significantly between the groups at baseline ( $p=0.20$; MD: 0.11 ; $95 \%$ CI: -0.06 to 0.27$)$. The $\mathrm{I}^{2}$ was $22 \%(p=0.26$; - Fig. 9).

Based on these results, PRF membranes were determined to be a promising alternative to autogenous gingival grafts in the treatment of Miller class I and II gingival recessions.

\section{Discussion}

This review considered high-impact articles from the field of periodontics to assess the reliability of the data on the use of PRF membranes as a substitute for the gold standard in the treatment of gingival recession. We did not limit the date of publication of the studies included to consider all of the literature available on the topic. Research in which PRF membranes were used in root coverage procedures is still scarce and is largely restricted to case studies or animal studies. We sought to standardize the methodology applied to the studies selected in an attempt to achieve a higher index of heterogeneity for the results.

Selecting articles based on their methodological protocols aided in obtaining uniformity in the data, lowered disparities between processes, and reduced the risk of bias. ${ }^{21}$ Even with randomized clinical trials with a high scientific weight, we found high indices of heterogeneity (greater than $90 \%$ ) for some of the parameters considered, particularly at baseline. Though considered high, however, these values are justifiable because it is unfeasible to standardize patients' initial conditions in many fields of medical research; there will always be small differences between study subjects. 
Table 3 General quantitative parameters

\begin{tabular}{|c|c|c|c|c|c|c|c|c|c|c|c|c|}
\hline \multicolumn{7}{|c|}{ Subepithelial connective tissue graft } & \multicolumn{6}{|c|}{ Platelet-rich fibrin } \\
\hline & Baseline & & $6 \mathrm{mo}$ & & $12 \mathrm{mo}$ & & Baseline & & $6 \mathrm{mo}$ & & $12 \mathrm{mo}$ & \\
\hline Author(s) & Mean \pm SD & $\mathrm{OA}$ & Mean \pm SD & $\mathrm{OA}$ & Mean \pm SD & OA & Mean \pm SD & $\mathrm{OA}$ & Mean \pm SD & $\mathrm{OA}$ & Mean \pm SD & $\mathrm{OA}$ \\
\hline \multicolumn{13}{|c|}{ Jankovic et al, 2012} \\
\hline PD & $0.86 \pm 0.47$ & 15 & $0.92 \pm 0.48$ & 15 & & & $0.74 \pm 0.53$ & 15 & $0.95 \pm 0.41$ & 15 & & \\
\hline CLI & $4.31 \pm 0.61$ & 15 & $1.35 \pm 0.38$ & 15 & & & $4.35 \pm 0.67$ & 15 & $1.48 \pm 0.4$ & 15 & & \\
\hline KM & $1.41 \pm 0.58$ & 15 & $2.85 \pm 0.45$ & 15 & & & $1.32 \pm 0.66$ & 15 & $2.2 \pm 0.54$ & 15 & & \\
\hline Recession & $3.45 \pm 0.84$ & 15 & $0.38 \pm 0.48$ & 15 & & & $3.51 \pm 0.7$ & 15 & $0.68 \pm 0.45$ & 15 & & \\
\hline \multicolumn{13}{|c|}{ Eren and Atilla, 2014} \\
\hline PD & $1.05 \pm 0.21$ & 44 & $1.45 \pm 0.60$ & 44 & & & $1.07 \pm 0.32$ & 44 & $1.09 \pm 0.29$ & 44 & & \\
\hline CLI & $3.68 \pm 0.73$ & 44 & $1.59 \pm 0.65$ & 44 & & & $3.75 \pm 0.7$ & 44 & $1.32 \pm 0.55$ & 44 & & \\
\hline KM & $2.41 \pm 1.20$ & 44 & $3.63 \pm 1.43$ & 44 & & & $2.58 \pm 1.37$ & 44 & $3.51 \pm 1.28$ & 44 & & \\
\hline Recession & $2.61 \pm 0.67$ & 44 & $0.16 \pm 0.33$ & 44 & & & $2.67 \pm 0.61$ & 44 & $0.18 \pm 0.32$ & 44 & & \\
\hline \multicolumn{13}{|c|}{ Eren et al, 2016} \\
\hline PD & $1.04 \pm 0.21$ & 24 & $1.12 \pm 0.6$ & 24 & & & $1.07 \pm 0.32$ & 24 & $1.09 \pm 0.29$ & 24 & & \\
\hline CLI & $3.68 \pm 0.73$ & 24 & $1.59 \pm 0.65$ & 24 & & & $3.75 \pm 0.7$ & 24 & $1.32 \pm 0.55$ & 24 & & \\
\hline KM & $2.41 \pm 1.20$ & 24 & $3.63 \pm 1.43$ & 24 & & & $2.58 \pm 1.37$ & 24 & $3.51 \pm 1.28$ & 24 & & \\
\hline Recession & $2.60 \pm 0.67$ & 24 & $0.16 \pm 0.33$ & 24 & & & $2.67 \pm 0.61$ & 24 & $0.18 \pm 0.32$ & 24 & & \\
\hline \multicolumn{13}{|c|}{ Tunalli et al, 2015} \\
\hline PD & $1.49 \pm 0.50$ & 22 & $1.13 \pm 0.35$ & 22 & $1.18 \pm 0.35$ & 22 & $1.33 \pm 0.59$ & 22 & $1.24 \pm 0.37$ & 22 & $1.18 \pm 0.33$ & 22 \\
\hline CLI & $5.20 \pm 1.49$ & 22 & $2.24 \pm 0.82$ & 22 & $2.16 \pm 0.79$ & 22 & $5.03 \pm 1.94$ & 22 & $2.27 \pm 0.92$ & 22 & $2.33 \pm 0.9$ & 22 \\
\hline KM & $2.43 \pm 0.52$ & 22 & $2.93 \pm 0.71$ & 22 & $3.03 \pm 0.74$ & 22 & $2.33 \pm 0.56$ & 22 & $2.93 \pm 0.7$ & 22 & $2.86 \pm 0.69$ & 22 \\
\hline Recession & $4.02 \pm 0.12$ & 22 & $1.14 \pm 0.04$ & 22 & $0.98 \pm 0.05$ & 22 & $4.45 \pm 0.18$ & 22 & $1.14 \pm 0.06$ & 22 & $1.05 \pm 0.04$ & 22 \\
\hline \multicolumn{13}{|c|}{ Uraz et al, 2015} \\
\hline PD & $1.38 \pm 0.58$ & 52 & $1.13 \pm 0.35$ & 52 & & & $1.53 \pm 0.17$ & 52 & $1.31 \pm 0.14$ & 52 & & \\
\hline CLI & $4.40 \pm 0.86$ & 52 & $1.18 \pm 0.35$ & 52 & & & $6.27 \pm 1.27$ & 52 & $2.48 \pm 1.41$ & 52 & & \\
\hline KM & $3.93 \pm 0.72$ & 52 & $5.11 \pm 0.76$ & 52 & & & $3.45 \pm 1.05$ & 52 & $4.63 \pm 0.86$ & 52 & & \\
\hline Recession & $3.11 \pm 0.80$ & 52 & $0.11 \pm 0.27$ & 52 & & & $4.73 \pm 1.3$ & 52 & $1.17 \pm 1.47$ & 52 & & \\
\hline \multicolumn{13}{|c|}{ Öncü, 2017} \\
\hline PD & $1.33 \pm 0.66$ & 30 & $1.17 \pm 0.38$ & 30 & & & $1.47 \pm 0.51$ & 30 & $1.17 \pm 0.38$ & 30 & & \\
\hline CLI & $5.53 \pm 1.07$ & 30 & $1.17 \pm 0.97$ & 30 & & & $5.37 \pm 1.07$ & 30 & $2.07 \pm 1.17$ & 30 & & \\
\hline KM & $2.60 \pm 0.77$ & 30 & $4.33 \pm 0.88$ & 30 & & & $2.70 \pm 0.70$ & 30 & $3.80 \pm 0.93$ & 30 & & \\
\hline Recession & $4.17 \pm 0.83$ & 30 & $0.68 \pm 0.92$ & 30 & & & $3.93 \pm 0.91$ & 30 & $0.90 \pm 1.03$ & 30 & & \\
\hline \multicolumn{13}{|c|}{ Mufti et al, 2017} \\
\hline \multicolumn{13}{|l|}{ PD } \\
\hline CLI & $4.12 \pm 1.258$ & 16 & $4.44 \pm 1.031$ & & & & $4.06 \pm 1.18$ & 16 & $2.81 \pm 0.83$ & & & \\
\hline KM & $4.31 \pm 0.793$ & 16 & $4.63 \pm 0.806$ & & & & $4.06 \pm 1.61$ & 16 & $4.44 \pm 2.25$ & & & \\
\hline Recession & $2.13 \pm 0.806$ & 16 & $1.38 \pm 0.806$ & & & & $2.19 \pm 0.98$ & 16 & $1.12 \pm 0.81$ & & & \\
\hline
\end{tabular}

Abbreviations: CLI, clinical level of insertion; KM, keratinized mucosa; M, mean; OA, operated area; PD, probing depth; R, recession; SD, standard derivation.

To ensure the quality of the information, all of the articles were assessed using the Jadad scale. ${ }^{18,19}$ On this scale, articles of greater scientific relevance receive scores greater than or equal to 3 . The studies included in this review reached received scores between 2 and 3 (-Table $\mathbf{1}$ ). The scores received were due to certain methodological limitations, such as the impossibility of performing a double-blind trial due to the inability to blind the surgeon to the procedure being performed. However, all of the patients in all of the studies included were blinded in both experimental and control groups, which allowed for a reliable evaluation of the postoperative results.

In each of the studies included in the review, the sample group was chosen using previously established inclusion and exclusion criteria to reduce bias. Unlike in the systematic review and meta-analysis by Moraschini et al, no 


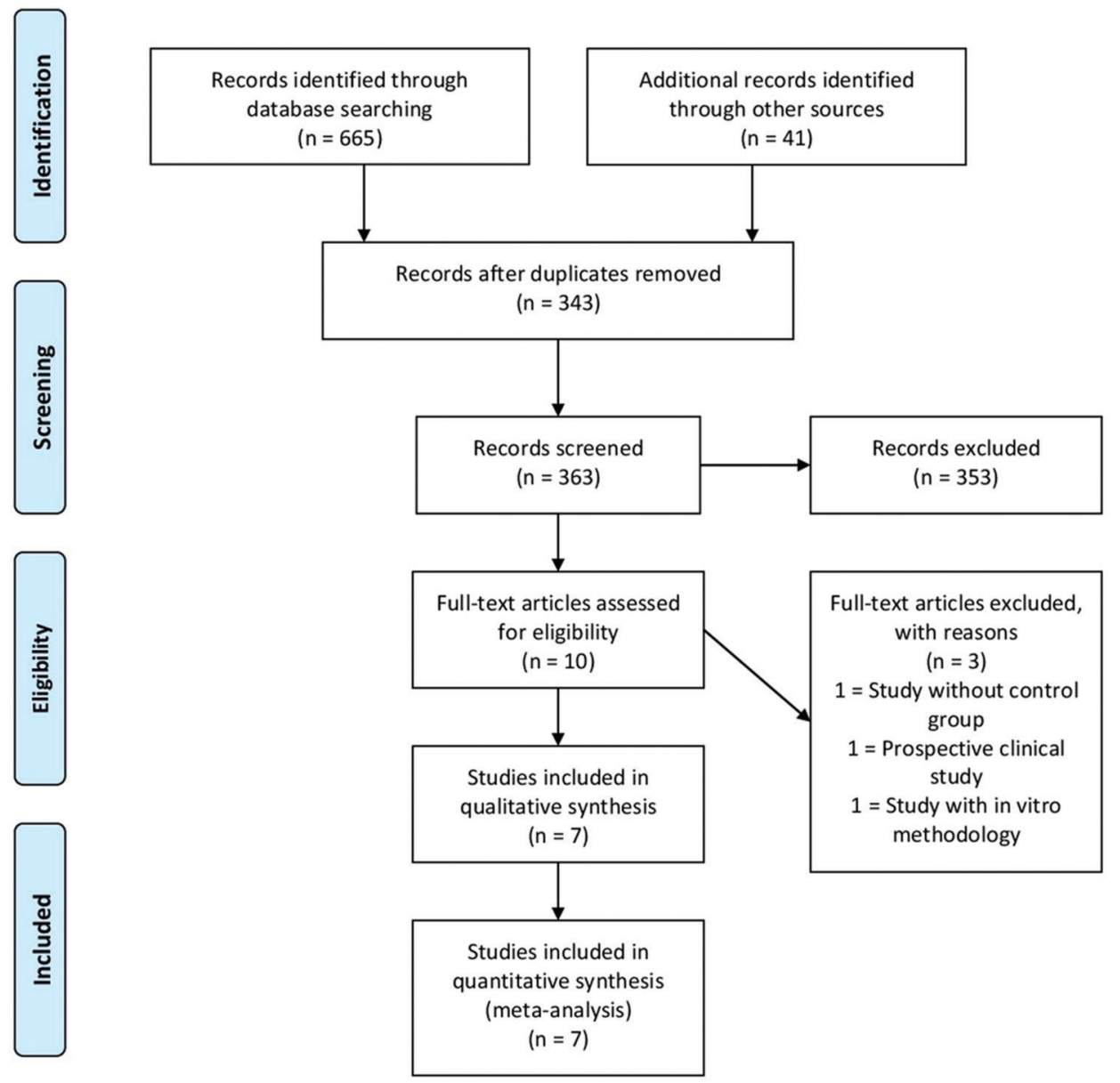

Fig. 1 Flow diagram of the literature search strategy.

studies were allowed in which smoking, heavy drinking, or systemic and/or periodontal diseases were not listed as exclusion criteria. ${ }^{22}$ It is known that clinical attachment loss tends to be greater in smokers than in nonsmokers due to the tissue damage caused by nicotine. ${ }^{2}$ Furthermore, the amount of cigarettes smoked daily and the length of time for which a patient has been a smoker have direct effects on the extent of periodontal damage: the greater the exposure to nicotine, the greater the damage to the periodontal tissue. ${ }^{2,23}$ Thus, the exclusion of smokers from the sample is prudent and minimizes external factors that may affect the clinical parameters in question.

To avoid biases caused by influences outside of the PRF membrane or SCTG implantation process, all of the articles chosen were ones which had adopted pre- and postoperative bacterial plaque control protocols. Uraz et al highlighted the role of the periodontist in correctly informing patients on brushing techniques, which are the keys to successfully maintaining native periodontal tissues. ${ }^{16,24}$ Brushing is able to break down oral biofilm, thus hindering the accumulation of debris on the gums or surfaces of the teeth, contributing to the prevention of gingivitis, slowing down the formation of calculus, and preserving the tissues involved., ${ }^{1,2}$ Dental professionals must emphasize the importance of adequate bacterial control in the postoperative period, since these microorganisms can exacerbate immune and inflammatory processes, thus compromising wound healing. ${ }^{25,26}$ However, postoperative morbidity creates difficulties in maintaining proper hygiene, and the use of chemical agents is necessary for bacterial control ${ }^{26}$ ( $\mathbf{- T a b l e s} \mathbf{4}$ and $\mathbf{5}$ ).

Bacterial plaque is considered the primary etiological factor in the development of periodontal diseases. Scaling and root planing are performed as the first stage of mechanical decontamination of the environment in any periodontal procedure so that the surgical site can be more biocompatible with the material being introduced. Only two articles included in this review failed to mention the use of this procedure, though no significant differences were found between their results and the results of the other studies ( $\mathbf{-}$ Table 5). ${ }^{12,13}$ Nevertheless, the benefits of mechanical debridement are well-established in the literature; the procedure aids in reducing postoperative contamination. ${ }^{27}$

Serving as the gold standard in the chemical control of biofilm, $0.12 \%$ chlorhexidine is frequently indicated as a bactericide in the postoperative period. However, the literature includes clinical protocols that differ in terms of the time of exposure, the frequency of use, and the duration of treatment ( - Table 4). Chlorhexidine-based agents act by altering 
Table 4 Drug protocol adopted by authors

\begin{tabular}{|c|c|c|c|c|c|c|c|c|}
\hline & & $\begin{array}{l}\text { Jankovic } \\
\text { et al, } 2012\end{array}$ & $\begin{array}{l}\text { Eren and } \\
\text { Atilla, } 2014\end{array}$ & $\begin{array}{l}\text { Tunalli } \\
\text { et al, } 2015\end{array}$ & $\begin{array}{l}\text { Uraz } \\
\text { et al, } 2015\end{array}$ & $\begin{array}{l}\text { Eren } \\
\text { et al, } \\
2016\end{array}$ & $\begin{array}{l}\text { Öncü, } \\
2017\end{array}$ & $\begin{array}{l}\text { Mufti } \\
\text { et al, } 2017\end{array}$ \\
\hline \multirow[t]{3}{*}{ Chlorhexidine } & $\%$ & $0.12 \%$ & NR & $0.12 \%$ & $0.12 \%$ & NR & $0.12 \%$ & $0.2 \%$ \\
\hline & $\begin{array}{l}\text { No. of mouth- } \\
\text { wash }\end{array}$ & NR & NR & NR & 1 & NR & 2 & 2 \\
\hline & No. of days & 21 & NR & 15 & NR & NR & NR & 21 \\
\hline \multirow[t]{2}{*}{ Antibiotic therapy } & Concentration & NR & NR & $\begin{array}{l}1,000 \mathrm{mg} \\
\text { Amoxicillin }\end{array}$ & NR & NR & NR & NR \\
\hline & No. of days & NR & NR & $\begin{array}{l}2 x \text { day for } \\
5 d\end{array}$ & NR & NR & NR & $5 d$ \\
\hline \multirow{2}{*}{$\begin{array}{l}\text { Anti-inflammatory } \\
\text { analgesic (AINES) }\end{array}$} & Concentration & NR & NR & NR & NR & NR & NR & NR \\
\hline & No. of days & NR & NR & NR & NR & $\begin{array}{l}2 x \text { day for } \\
5 d\end{array}$ & NR & $5 d$ \\
\hline \multirow[t]{3}{*}{ Anesthetic } & Salt type & NR & $\begin{array}{l}\text { Lidocaine } \\
2 \%\end{array}$ & $\begin{array}{l}\text { Articaine } \\
2 \%\end{array}$ & $\begin{array}{l}\text { Lidocaine } \\
2 \%\end{array}$ & NR & NR & NR \\
\hline & $\begin{array}{l}\text { Vasoconstric- } \\
\text { tor }\end{array}$ & NR & $\begin{array}{l}\text { Epinephrine } \\
1: 100.000\end{array}$ & $\begin{array}{l}\text { Epineph- } \\
\text { rine } \\
1: 100.000\end{array}$ & $\begin{array}{l}\text { Epineph- } \\
\text { rine } \\
1: 100.000\end{array}$ & NR & NR & NR \\
\hline & No. of tubes & NR & NR & NR & NR & NR & NR & NR \\
\hline $\begin{array}{l}\text { Radical chemical } \\
\text { conditioning }\end{array}$ & $\begin{array}{l}\text { Biomodifier } \\
\text { agent }\end{array}$ & NR & NR & NR & $\begin{array}{l}\text { Not per- } \\
\text { formed }\end{array}$ & NR & NR & NR \\
\hline \multirow[t]{2}{*}{$\begin{array}{l}\text { Oral hygiene } \\
\text { (control of plaque) }\end{array}$} & $\begin{array}{l}\text { Professional } \\
\text { (OHI; RSS; PRC) }\end{array}$ & $\begin{array}{l}\mathrm{OHI} \\
\text { RSS } \\
\text { PRC } \\
\text { Ultrasound }\end{array}$ & $\begin{array}{l}\text { OHI } \\
\text { RSS } \\
\text { PRC }\end{array}$ & $\begin{array}{l}\mathrm{OHI} \\
\text { RSS } \\
\text { PRC } \\
\text { Ultrasound }\end{array}$ & $\begin{array}{l}\mathrm{OHI} \\
\text { RSS } \\
\text { PRC } \\
\text { Ultrasound }\end{array}$ & $\mathrm{OHI}$ & $\mathrm{OHI}$ & $\begin{array}{l}\mathrm{OHI} \\
\text { RSS }\end{array}$ \\
\hline & $\begin{array}{l}\text { Patient } \\
\text { (brushing/ } \\
\text { technique) }\end{array}$ & $\begin{array}{l}\text { Brushing/ } \\
\text { NR }\end{array}$ & $\begin{array}{l}\text { Brushing/ } \\
\text { NR }\end{array}$ & $\begin{array}{l}\text { Brushing/ } \\
\text { NR }\end{array}$ & $\begin{array}{l}\text { Brushing/ } \\
\text { Stillman } \\
\text { modified }\end{array}$ & $\begin{array}{l}\text { Brushing/ } \\
\text { NR }\end{array}$ & $\begin{array}{l}\text { Brushing/ } \\
\text { NR }\end{array}$ & $\begin{array}{l}\text { Brushing/ } \\
\text { NR }\end{array}$ \\
\hline
\end{tabular}

Abbreviations: NM, not reporter; OHI, oral hygiene instructions; PRC, prophylaxis with rubber cup; RSS, root scaling and straightening.

Table 5 Oral hygiene protocol

\begin{tabular}{|c|c|c|c|c|c|c|c|c|}
\hline & & $\begin{array}{l}\text { Jankovic } \\
\text { et al, } 2012\end{array}$ & $\begin{array}{l}\text { Eren and } \\
\text { Atilla, } 2014\end{array}$ & $\begin{array}{l}\text { Tunalli } \\
\text { et al, } \\
2015\end{array}$ & $\begin{array}{l}\text { Uraz } \\
\text { et al, } \\
2015\end{array}$ & $\begin{array}{l}\text { Eren } \\
\text { et al, } \\
2016\end{array}$ & $\begin{array}{l}\text { Öncü, } \\
2017\end{array}$ & $\begin{array}{l}\text { Mufti } \\
\text { et al, } \\
2017\end{array}$ \\
\hline \multirow[t]{2}{*}{$\begin{array}{l}\text { Professional (OHI; } \\
\text { RSS; PRC) }\end{array}$} & $\begin{array}{l}\text { Preop- } \\
\text { erative }\end{array}$ & $\begin{array}{l}\text { OHI } \\
\text { RSS } \\
\text { PRC }\end{array}$ & NR & NR & $\begin{array}{l}\text { OHI } \\
\text { RSS } \\
\text { PRC } \\
\text { Ultrasound }\end{array}$ & NR & $\mathrm{OHI}$ & $\begin{array}{l}\mathrm{OHI} \\
\text { RSS }\end{array}$ \\
\hline & $\begin{array}{l}\text { Postop- } \\
\text { erative }\end{array}$ & $\begin{array}{l}\text { OHI } \\
\text { RSS } \\
\text { PRC }\end{array}$ & $\begin{array}{l}\text { OHI } \\
\text { RSS } \\
\text { PRC }\end{array}$ & $\begin{array}{l}\text { OHI } \\
\text { RSS } \\
\text { PRC } \\
\text { Ultrasound }\end{array}$ & $\begin{array}{l}\text { OHI } \\
\text { RSS } \\
\text { PRC } \\
\text { Ultrasound }\end{array}$ & $\mathrm{OHI}$ & $\mathrm{OHI}$ & $\mathrm{OHI}$ \\
\hline \multirow{2}{*}{$\begin{array}{l}\text { Patient } \\
\text { (brushing/ } \\
\text { technique) }\end{array}$} & $\begin{array}{l}\text { Preop- } \\
\text { erative }\end{array}$ & $\begin{array}{l}\text { Brushing/ } \\
\text { NR }\end{array}$ & NR & NR & NR & NR & NR & NR \\
\hline & $\begin{array}{l}\text { Postop- } \\
\text { erative }\end{array}$ & $\begin{array}{l}\text { Brushing/ } \\
\text { NR }\end{array}$ & $\begin{array}{l}\text { Brushing/ } \\
\text { NR }\end{array}$ & $\begin{array}{l}\text { Brushing/ } \\
\text { NR }\end{array}$ & $\begin{array}{l}\text { Brushing/ } \\
\text { Stillman } \\
\text { modified }\end{array}$ & $\begin{array}{l}\text { Brushing/ } \\
\text { NR }\end{array}$ & $\begin{array}{l}\text { Brushing/ } \\
\text { NR }\end{array}$ & $\begin{array}{l}\text { Brushing/ } \\
\text { NR }\end{array}$ \\
\hline
\end{tabular}

Abbreviations: NM, not reporter; $\mathrm{OHI}$, oral hygiene instructions; PRC, prophylaxis with rubber cup; RSS, root scaling and straightening.

bacterium adsorption to the teeth through the reduction of the biofilm, as well as by killing microorganisms through the penetration of the cell wall. ${ }^{28}$

The medications prescribed also varied from one study to the next, particularly in terms of the use of postoperative antibiotics ( - Table 4 ). There is no consensus in the literature regarding the use of systemic antibiotics as part of periodontal surgery, and opinions vary on their prescription and methods of use. Herrera et al performed a systematic review and concluded that the prescription of antibiotics in the postoperative period may be beneficial in reducing microorganisms and preventing infections that can influence tissue 


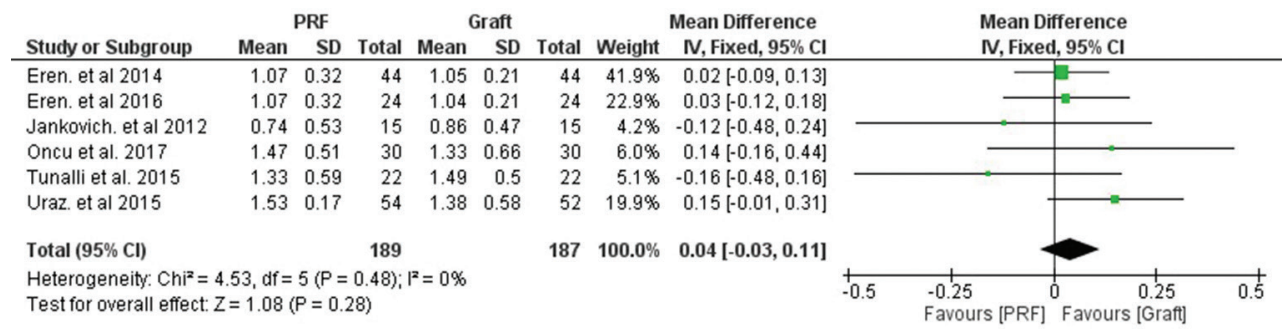

Fig. 2 Comparison between PRF and SCTGs in the clinical parameter "probing depth" after 6 months. PRF, platelet-rich fibrin; SCTGs; subepithelial connective tissue grafts.

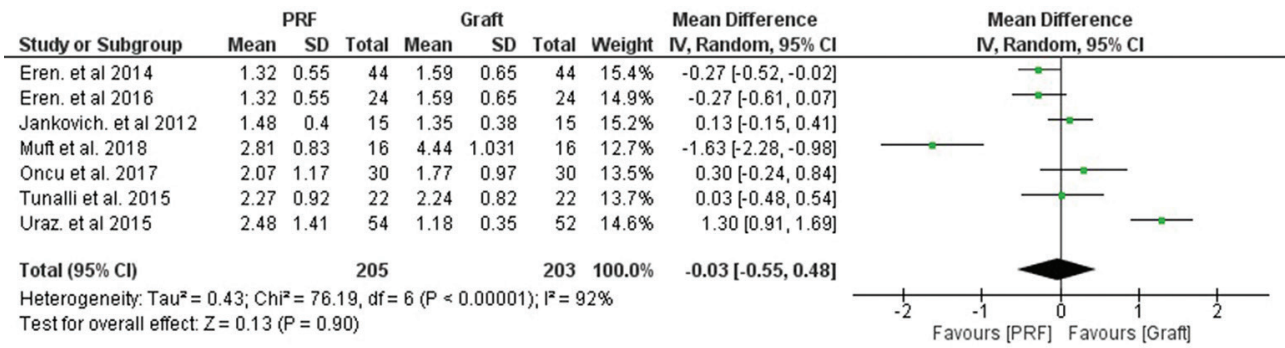

Fig. 3 Comparison between PRF and SCTGs in the clinical parameter "probing depth" in baseline. PRF, platelet-rich fibrin; SCTGs, subepithelial connective tissue grafts.

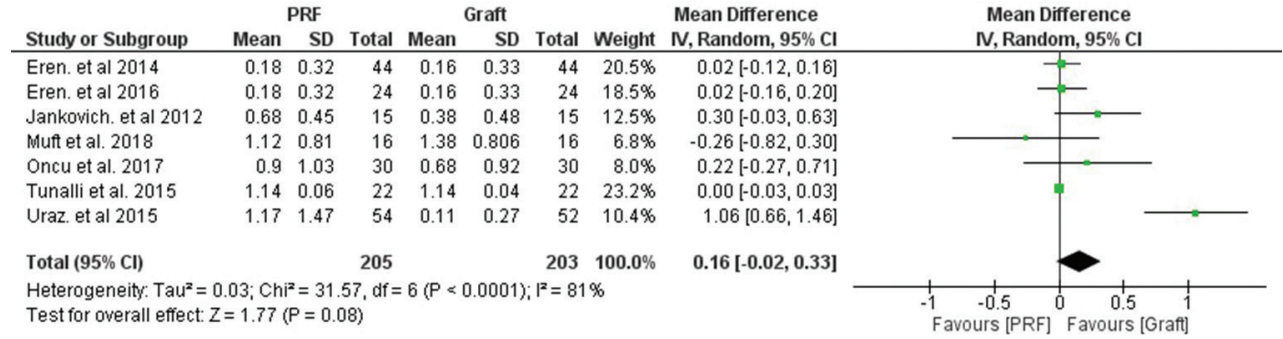

Fig. 4 Comparison between PRF and SCTGs in clinical parameter "clinical attachment levels" after 6 months. PRF, platelet-rich fibrin; SCTGs, subepithelial connective tissue grafts.

\begin{tabular}{|c|c|c|c|c|c|c|c|c|c|c|c|}
\hline \multirow[b]{2}{*}{ Study or Subgroup } & \multicolumn{3}{|c|}{ PRF } & \multicolumn{3}{|c|}{ Graft } & \multicolumn{2}{|r|}{ Mean Difference } & \multirow{2}{*}{\multicolumn{3}{|c|}{$\begin{array}{l}\text { Mean Difference } \\
\text { N, Fixed, } 95 \% \mathrm{CI}\end{array}$}} \\
\hline & Mean & SD & Total & Mean & SD & Total & Weight & IV, Fixed, $95 \%$ CI & & & \\
\hline Eren. et al 2014 & 3.51 & 1.28 & 44 & 3.63 & 1.43 & 44 & $9.0 \%$ & $-0.12[-0.69,0.45]$ & & & \\
\hline Eren. et al 2016 & 3.51 & 1.28 & 24 & 3.63 & 1.43 & 24 & $4.9 \%$ & $-0.12[-0.89,0.65]$ & & & \\
\hline Jankovich. et al 2012 & 2.2 & 0.54 & 15 & 2.85 & 0.45 & 15 & $22.9 \%$ & $-0.65[-1.01,-0.29]$ & - & & \\
\hline Muft et al. 2018 & 4.44 & 2.25 & 16 & 4.63 & 0.806 & 16 & $2.1 \%$ & $-0.19[-1.36,0.98]$ & & & \\
\hline Oncu et al. 2017 & 3.8 & 0.93 & 30 & 4.33 & 0.88 & 30 & $13.8 \%$ & $-0.53[-0.99,-0.07]$ & & & \\
\hline Tunalli et al. 2015 & 2.93 & 0.7 & 22 & 2.93 & 0.71 & 22 & $16.7 \%$ & $0.00[-0.42,0.42]$ & & & \\
\hline Uraz. et al 2015 & 4.63 & 0.86 & 54 & 5.11 & 0.76 & 52 & $30.5 \%$ & $-0.48[-0.79,-0.17]$ & $\rightarrow-$ & & \\
\hline Total $(95 \% \mathrm{Cl})$ & & & 205 & & & 203 & $100.0 \%$ & $-0.39[-0.56,-0.22]$ & & & \\
\hline $\begin{array}{l}\text { Heterogeneity: } \mathrm{Chi}^{2}= \\
\text { Test for overall effect: }\end{array}$ & $\begin{array}{l}56, \mathrm{df}= \\
=4.48\end{array}$ & $\begin{array}{l}6(P= \\
P<0.0\end{array}$ & $\begin{array}{l}0.27) ; \\
0001)\end{array}$ & $I^{2}=21 \%$ & & & & & $\begin{array}{cc}1 & 1 \\
-2 & -1 \\
& \end{array}$ & \begin{tabular}{|lr}
0 & 1 \\
0 &
\end{tabular} & 1 \\
\hline
\end{tabular}

Fig. 5 Comparison between PRF and SCTGs in clinical parameter "clinical attachment levels" in baseline. PRF, platelet-rich fibrin; SCTGs, subepithelial connective tissue grafts.

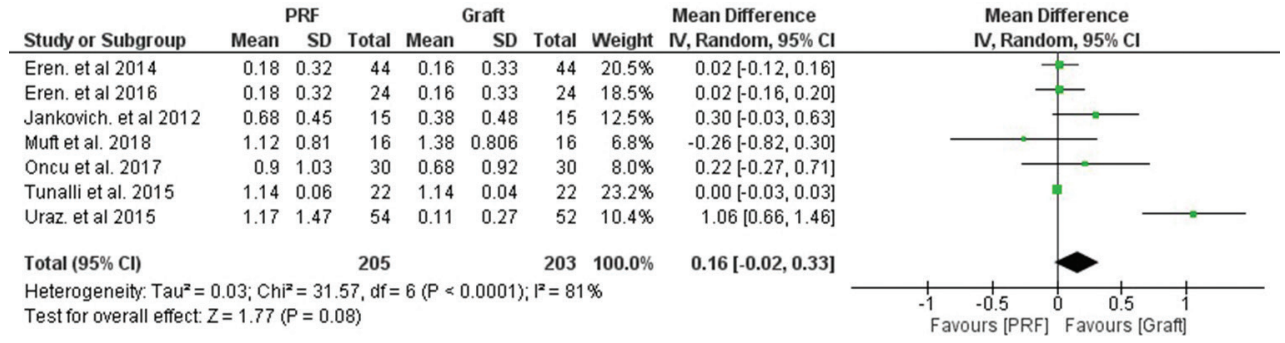

Fig. 6 Comparison between PRF and SCTGs in the clinical parameter "gingival recession" after 6 months. PRF, platelet-rich fibrin; SCTGs, subepithelial connective tissue grafts. 


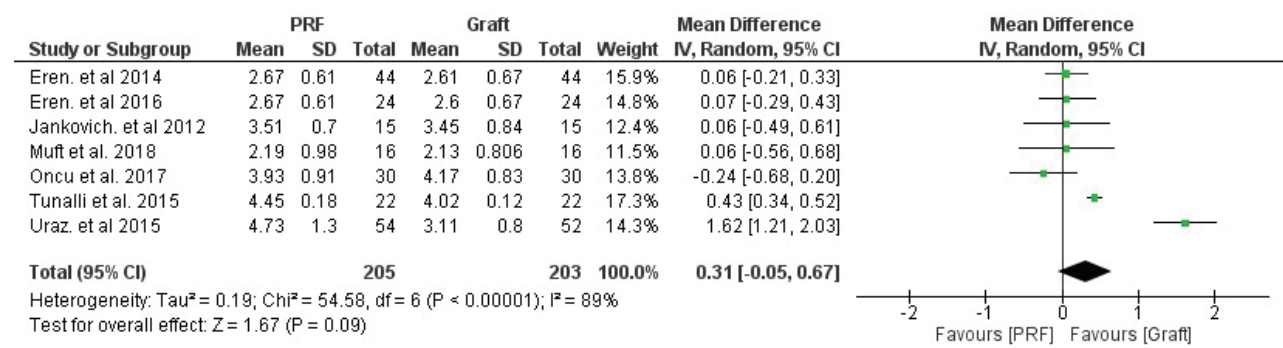

Fig. 7 Comparison between PRF and SCTGs in the clinical parameter "gingival recession" in baseline. PRF, platelet-rich fibrin; SCTGs, subepithelial connective tissue grafts.

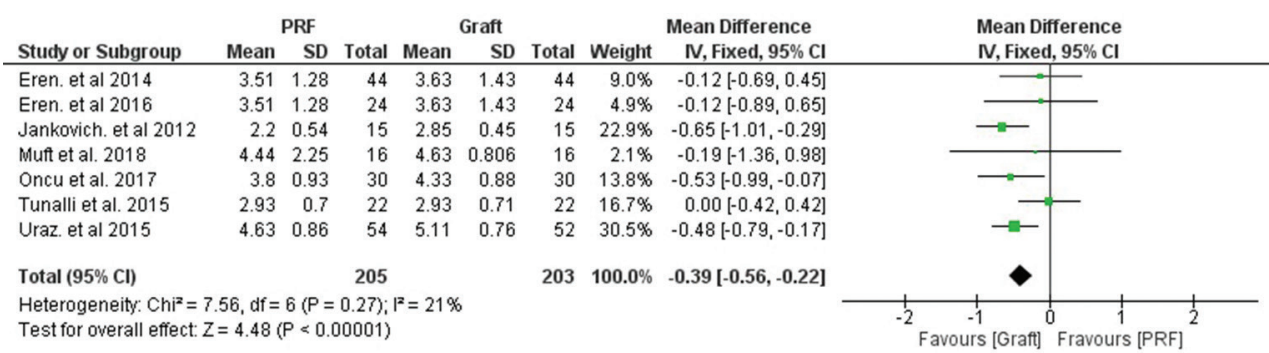

Fig. 8 Comparison between PRF and SCTGs in the clinical parameter "keratinized mucosa" after 6 months. PRF, platelet-rich fibrin; SCTGs, subepithelial connective tissue grafts.

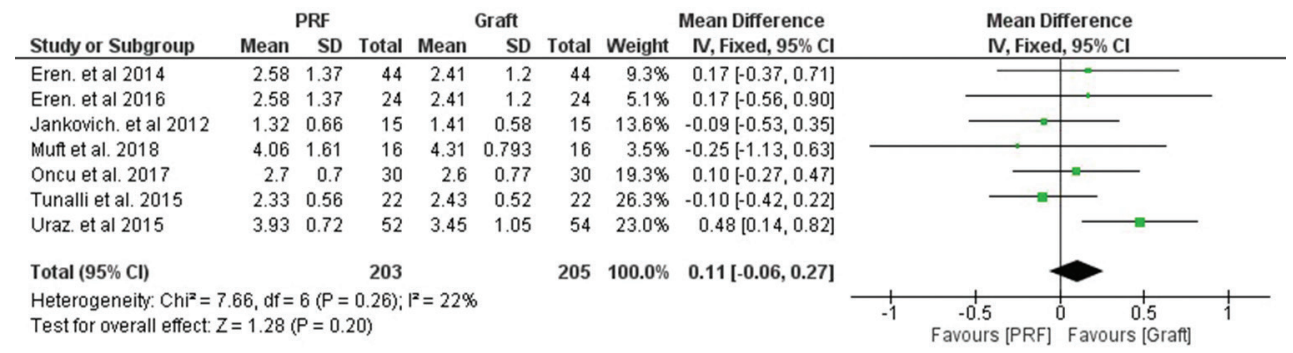

Fig. 9 Comparison between PRF and SCTGs in the clinical parameter "keratinized mucosa" in baseline. PRF, platelet-rich fibrin; SCTGs, subepithelial connective tissue grafts.

healing. ${ }^{29}$ The authors supported the start of antibiotic therapy soon after the completion of scaling and continued antibiotic treatment for a short period of time. However, Liu et al performed their own systematic review and determined that the rate of infection following periodontal surgery involving antibiotic therapy did not differ significantly from surgeries in which antibiotics were not administered; the authors therefore argued that the use of antibiotics to prevent postoperative infection is not justified in these procedures. ${ }^{30}$ There is still no consensus regarding the use of antibiotics, despite the fact that microbial infections are often the culprit behind delayed or failed healing. ${ }^{26}$ Even with inconsistencies between the protocols, the results of the studies included in the current literature review did not differ significantly in their reports of postoperative infections or complications.

When the use of pain medication was considered, it was found that all of the papers recommended nonsteroidal anti-inflammatory drugs (NSAIDs), though there were slight differences in the type of drug and the dosages ( - Table 4). Unlike the use of antibiotics, the use of NSAIDs for pain associated with periodontal surgery is widely supported in the literature. ${ }^{31}$ Because it is a clear sign of inflammation and is directly associated with immunological processes, pain is an important variable to be measured in studies comparing wound healing. However, only three of the studies cited this variable. In the research, patients used a visual analog scale which described their pain, sensitivity, and healing progress for both surgical sites. In all of the articles, there were significant differences between the scores, and the PRF groups consistently reported less pain; greater pain and discomfort was reported by control (SCTG) groups in 7 days after surgery. ${ }^{9,13,14}$

Regardless of the surgical technique used to achieve root coverage, a reduction in probing depth, gains in clinical attachment, and an increase in keratinized mucosa are expected outcomes. ${ }^{4}$ The procedure employed in the articles represents the gold standard in studies comparing root coverage treatment because it typically achieves the best outcomes, whether in terms of gains in height, greater tissue thickness, or improved appearance.

\section{Periodontal Parameters: Discussion}

When tissue gains were considered in terms of the periodontal parameters evaluated in the studies (probing depth, clinical attachment level, gingival recession, and keratinized mucosa), the width of the keratinized mucosa at sites with 
gingival recession was the only variable that differed significantly between the control groups (SCTG) and the experimental groups (PRF) $(p<0.0001)$. This outcome is likely due to the potential of the conjunctiva matrix of the autogenous graft to support migration and cell adhesion, thus contributing to tissue repair. ${ }^{14}$

However, it is important to note that researchers have not reached a consensus regarding the amount of keratinized mucosa required to maintain periodontal and peri-implant health from biological and cosmetic perspectives. ${ }^{32}$

Some studies have reported that even a small section of keratinized gingiva can aid in the long-term maintenance of the tissues surrounding teeth and implants. Keratinized gingiva is protective by nature and creates resistance to muscle use, restorative interventions, traumatic brushing techniques, and bacterial plaque; it also stabilizes soft and hard tissues and contributes to oral hygiene and improved

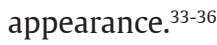

However, other studies have concluded that keratinized gingiva is not a determining factor in soft tissue health, since it is not associated with increased bone loss, periodontal diseases, or peri-implant diseases. ${ }^{37-40}$

The amount of keratinized mucosa was the only parameter in which the results of the use of PRF were not statistically consistent with the gold standard. Because of the issue of the true importance of keratinized mucosa in dental and peri-implant health, the lack of statistical differences between the treatments in terms of the other parameters (probing depth, clinical attachment level, and gingival recession) is a surprising finding; it shifts paradigms and suggests a promising future for the use of PRF membranes as an alternative to SCTGs in exposed root coverage procedures. We know that SCTGs are the first choice in root coverage cases; however, dental surgeons require additional evidence-based options for situations in which the gold standard is not ideal, such as cases with financial restrictions, cases in which a limited amount of donor tissue is available for multiple recessions, and patients for whom postoperative morbidity is higher due to the exposure of a second surgical (donor) site.

\section{Molecular Parameters: Discussion}

Due to the molecular aspects of wound healing, this systematic review considered studies with follow-up periods of at least 6 months. This time is necessary for a more effective assessment of wound healing processes and changes in the periodontal parameters considered..$^{10,13}$

PRF membranes enable the gradual and continual release of growth factors, a process which contributes to the healing of soft tissues. ${ }^{41}$ This process includes a variety of cell types regulated by molecules which are themselves produced as part of the recipient's immunological response. These molecules include metalloproteases (MMPs) and their tissue inhibitors (TIMPs), which are responsible for remodeling the tissue collagen matrix. ${ }^{15,42}$

MMPs make up a family of proteolytic enzymes that are active in pathological and physiological processes involved in collagen remodeling and tissue repair. ${ }^{40}$ These proteins are divided into two groups and are regulated by TIMPs, which are endogenous proteins. TIMPs are able to inhibit MMP activity and are fundamental in tissue repair. ${ }^{13,43}$

In homeostasis, MMPs and TIMPs are in equilibrium, but trauma such as that which is caused by surgery can trigger substantial metabolic and immunological reactions that disrupt this balance and affect the tissue repair process. ${ }^{15,44}$ Despite the role of these molecules in wound healing, only one of the articles included in this review addressed the molecular aspects of the healing process. The authors evaluated changes in MMP and TIMP levels over time in the control group (SCTG) and the experimental group (PRF). ${ }^{15}$ Eren et al found an increased release of TIMP-1 accompanied by decreased MMP-8 secretion in the early (10-day) postoperative period. These processes contribute to tissue healing through the synthesis of the collagen matrix. When compared with sites in the control group, the sites treated with PRF exhibited even lower levels of MMP-8 and higher TIMP-1 expression, results which suggest a more accelerated healing process accompanied by a substantial reduction in local inflammation. ${ }^{15}$

Other molecules, such as endothelial growth factors (including VEGF), act as avid stimulators of angiogenesis, thus increasing blood vessel synthesis. ${ }^{12,45}$

Platelets and leukocytes are involved in VEGF expression; they are at their highest concentrations in the first hours after the clotting process, and VEGF levels gradually increase during the tissue healing process. ${ }^{43}$

Rapid neovascularization is vital to tissue repair and regeneration, since angiogenesis enables the migration of tissue cells adjacent to the matrix, which, in turn, enables the repopulation of the injured area and the start of tissue repair. ${ }^{9}$ However, for angiogenesis to occur, cytokine adhesion and new vessels must be supported. ${ }^{44}$ Studies have shown that the three-dimensional structure of PRF allows for the adhesion of new vessels and stimulates the activity of regulatory cytokines trapped in its fibrin mesh. For these reasons, PRF can be considered an ideal biomaterial in terms of tissue engineering: it provides a mesh that acts as a scaffold, viable cells for tissue repopulation, and molecules that stimulate repair. 46,47

These findings have been clinically confirmed in the articles included herein. Jankovic et al report on the potential for accelerated tissue repair provided by PRF membranes. As early as the second week after surgery, they observed a more advanced healing process in association with less pain and discomfort when compared with areas treated with the conventional graft. ${ }^{9}$ In a histomorphometric analysis comparing PRF to the gold standard, Eren et al found that the integration, thickness, and appearance of the epithelial layers were similar between the two grafts. After 6 months of follow-up, the experimental group (PRF) still exhibited greater epithelial extension toward the connective tissue, which increased mechanical resistance at the site. ${ }^{12}$ In addition, the analysis of molecular markers (CD31, an adhesion molecule between endothelial cells and leukocytes, and CD34, a marker of endothelial cell proliferation during angiogenesis) revealed that vascular formation and tissue 
maturation occur earlier in sites treated with PRF than in those treated with SCTGs, which would justify the relatively early reduction in pain. ${ }^{14,15}$

However, it is important to note that, even with a relevant sample size (22 patients and 408 surgical sites), variables such as healing time, postoperative pain, graft thickness, and methodology details may influence the predictability of treatment. Therefore, we suggest the preparation of larger studies with longer follow-up times and more detailed methodological descriptions so that the advantages of using this biomaterial can be confirmed and understood.

Based on the statistical comparison of the findings from the literature, PRF exhibits characteristics that enable its use as an important aid in the wound healing process. Surgeons should therefore consider its use in the treatment of gingival recession as an alternative to SCTGs.

\section{Clinical Relevance}

Scientific Rationale for the Study: The treatment of gingival recessions using subepithelial connective tissue grafts has numerous limitations, including restricted supply in multiple recessions, postoperative morbidity (donor site), and increased surgical time.

Principal Findings: Platelet-rich fibrin (PRF) is a fully autogenous material that, in a single device, provides a mesh that acts as scaffold, viable cells to tissue repopulation, and molecules that stimulate repair.

Practical Implications: Due to its regenerative potential, PRF membranes are a promising alternative to gingival autogenous grafts, with encouraging results in cases of root coverage.

\section{Funding}

None.

\section{Conflict of Interest}

None declared.

\section{References}

1 Cortellini P, Bissada NF. Mucogingival conditions in the natural dentition: narrative review, case definitions, and diagnostic considerations. J Periodontol 2018;89(Suppl 1):S204-S213

2 Jepsen S, Caton JG, Albandar JM, et al. Periodontal manifestations of systemic diseases and developmental and acquired conditions: consensus report of workgroup 3 of the 2017 World Workshop on the Classification of Periodontal and Peri-Implant Diseases and Conditions. J Clin Periodontol 2018;45(Suppl 20) :S219-S229

3 Miller PD Jr. A classification of marginal tissue recession. Int J Periodontics Restorative Dent 1985;5(2):8-13

4 Aguirre-Zorzano LA, García-De La Fuente AM, Estefanía-Fresco $\mathrm{R}$, Marichalar-Mendía X. Complications of harvesting a connective tissue graft from the palate. A retrospective study and description of a new technique. J Clin Exp Dent 2017;9(12):e1439-e1445

5 Perotto S, Romano F, Cricenti L, Gotti S, Aimetti M. Vascularization and innervation of connective tissue grafts in the treatment of gingival recessions: a histologic and immunohistochemical study. Int J Periodontics Restorative Dent 2017;37(4):551-558
6 Amine K, El Amrani Y, Chemlali S, Kissa J. Alternatives to connective tissue graft in the treatment of localized gingival recessions: a systematic review. J Stomatol Oral Maxillofac Surg 2018;119(1):25-32

7 Shah R, Triveni MG, Thomas R, Mehta DS. An update on the protocols and biologic actions of platelet rich fibrin in dentistry. Eur J Prosthodont Restor Dent 2017;25(2):64-72

8 Agarwal SK, Jhingran R, Bains VK, Srivastava R, Madan R, Rizvi I. Patient-centered evaluation of microsurgical management of gingival recession using coronally advanced flap with platelet-rich fibrin or amnion membrane: a comparative analysis. Eur J Dent 2016;10(1):121-133

9 Jankovic S, Aleksic Z, Klokkevold P, et al. Use of platelet-rich fibrin membrane following treatment of gingival recession: a randomized clinical trial. Int J Periodontics Restorative Dent 2012;32(2):e41-e50

10 Eren G, Atilla G. Platelet-rich fibrin in the treatment of localized gingival recessions: a split-mouth randomized clinical trial. Clin Oral Investig 2014;18(8):1941-1948

11 Tunalı M, Özdemir H, Arabacı, T, Gürbüzer B, Pikdöken L, Firatli E. Clinical evaluation of autologous platelet-rich fibrin in the treatment of multiple adjacent gingival recession defects: a 12-month study. Int J Periodontics Restorative Dent 2015;35(1):105-114

12 Eren G, Kantarcı A, Sculean A, Atilla G. Vascularization after treatment of gingival recession defects with platelet-rich fibrin or connective tissue graft. Clin Oral Investig 2016;20(8):2045-2053

13 Öncü E. The use of platelet-rich fibrin versus subepithelial connective tissue graft in treatment of multiple gingival recessions: a randomized clinical trial. Int J Periodontics Restorative Dent 2017;37(2):265-271

14 Mufti S, Dadawala SM, Patel P, Shah M, Dave DH. Comparative evaluation of platelet-rich fibrin with connective tissue grafts in the treatment of Miller's class I gingival recessions. Contemp Clin Dent 2017;8(4):531-537

15 Eren G, Tervahartiala T, Sorsa T, Atilla G. Cytokine (interleukin-1beta) and MMP levels in gingival crevicular fluid after use of platelet-rich fibrin or connective tissue graft in the treatment of localized gingival recessions. J Periodontal Res 2016;51(4):481-488

16 Uraz A, Sezgin Y, Yalim M, Taner IL, Cetiner D. Comparative evaluation of platelet-rich fibrin membrane and connective tissue graft in the treatment of multiple adjacent recession defects: a clinical study. J Dent Sci 2015;10:36-45

17 Samani MK, Saberi BV, Ali Tabatabaei SM, Moghadam MG. The clinical evaluation of platelet-rich plasma on freegingivalgraft's donor site wound healing. Eur J Dent 2017;11(4):447-454

18 Jadad AR, Moore RA, Carroll D, et al. Assessing the quality of reports of randomized clinical trials: is blinding necessary? Control Clin Trials 1996;17(1):1-12

19 Khan KS, Daya S, Jadad A. The importance of quality of primary studies in producing unbiased systematic reviews. Arch Intern Med 1996;156(6):661-666

20 de Medeiros FCFL, Kudo GAH, Leme BG, et al. Dental implants in patients with osteoporosis: a systematic review with meta-analysis. Int J Oral Maxillofac Surg 2018;47(4):480-491

21 Carvalho APV, Silva V, José Grande A. Avaliação do risco de viés de ensaios clínicos randomizados pela ferramenta da colaboração Cochrane. Diagn Tratamento 2013;18:38-44

22 Moraschini V, Barboza Edos S. Use of platelet-rich fibrin membrane in the treatment of gingival recession: a systematic review and meta-analysis. J Periodontol 2016;87(3):281-290

23 Hennequin-Hoenderdos NL, Slot DE, Van der Weijden GA. The incidence of complications associated with lip and/ or tongue piercings: a systematic review. Int J Dent Hyg 2016;14(1):62-73 
24 Arora S, Agnihotri N. Platelet derived biomaterials for therapeutic use: review of technical aspects. Indian J Hematol Blood Transfus 2017;33(2):159-167

25 Sethi KS, Karde PA, Joshi CP. Comparative evaluation of sutures coated with triclosan and chlorhexidine for oral biofilm inhibition potential and antimicrobial activity against periodontal pathogens: an in vitro study. Indian J Dent Res 2016;27(5):535-539

26 Bosshardt DD. The periodontal pocket: pathogenesis, histopathology and consequences. Periodontol 2000 2018;76(1):43-50

27 Goel K. Supracrestal non-surgical therapy in periodontal diseases. JNMA J Nepal Med Assoc 2018;56(209):544-546

28 Haydari M, Bardakci AG, Koldsland OC, Aass AM, Sandvik L, Preus HR. Comparing the effect of $0.06 \%-, 0.12 \%$ and $0.2 \%$ chlorhexidine on plaque, bleeding and side effects in an experimental gingivitis model: a parallel group, double masked randomized clinical trial. BMC Oral Health 2017;17(1):118

29 Herrera D, Alonso B, León R, Roldán S, Sanz M. Antimicrobial therapy in periodontitis: the use of systemic antimicrobials against the subgingival biofilm. J Clin Periodontol 2008;35(8, Suppl):45-66

30 Liu Y, Duan D, Xin Y, et al. A review of the literature: antibiotic usage and its relevance to the infection in periodontal flaps. Acta Odontol Scand 2017;75(4):288-293

31 Kashefimehr A, Babaloo A, Ghanizadeh M, Ghasemi SH, Mollazadeh $\mathrm{H}$. Effect of prophylactic administration of Novafen for periodontal surgery on postoperative pain relief. J Med Life 2017;10(2):127-130

32 Kim BS, Kim YK, Yun PY, et al. Evaluation of peri-implant tissue response according to the presence of keratinized mucosa. Oral Surg Oral Med Oral Pathol Oral Radiol Endod 2009;107(3):e24-e28

33 Lang NP, Löe $H$. The relationship between the width of keratinized gingiva and gingival health. J Periodontol 1972;43(10):623-627

34 Marquez IC. The role of keratinized tissue and attached gingiva in maintaining periodontal/peri-implant health. Gen Dent 2004;52(1):74-78

35 Thoma DS, Naenni N, Figuero E, et al. Effects of soft tissue augmentation procedures on peri-implant health or disease: a systematic review and meta-analysis. Clin Oral Implants Res 2018;29(suppl 15) :32-49
36 Gobbato L, Avila-Ortiz G, Sohrabi K, Wang CW, Karimbux $\mathrm{N}$. The effect of keratinized mucosa width on peri-implant health: a systematic review. Int J Oral Maxillofac Implants 2013;28(6):1536-1545

37 Wennström JL. Lack of association between width of attached gingiva and development of soft tissue recession. A 5-year longitudinal study. J Clin Periodontol 1987;14(3):181-184

38 Wennström JL, Bengazi F, Lekholm U. The influence of the masticatory mucosa on the peri-implant soft tissue condition. Clin Oral Implants Res 1994;5(1):1-8

39 Cornelini R, Cangini F, Covani U, Barone A, Buser D. Immediate restoration of single-tooth implants in mandibular molar sites: a 12-month preliminary report. Int J Oral Maxillofac Implants 2004;19(6):855-860

40 Chiu YW, Lee SY, Lin YC, Lai YL. Significance of the width of keratinized mucosa on peri-implant health. J Chin Med Assoc 2015;78(7):389-394

41 Caruana A, Savina D, Macedo JP, Soares SC. From platelet-rich plasma to advanced platelet-rich fibrin: biological achievements and clinical advances in modern surgery. Eur J Dent 2019;13(2):280-286

42 Chicharro-Alcántara D, Rubio-Zaragoza M, Damiá-Giménez E, et al. Platelet rich plasma: new insights for cutaneous wound healing management. J Funct Biomater 2018;9(1):E10

43 Patel S, Maheshwari A, Chandra A. Biomarkers for wound healing and their evaluation. J Wound Care 2016;25(1):46-55

44 Rohani MG, Parks WC. Matrix remodeling by MMPs during wound repair. Matrix Biol 2015;44-46:113-121

45 Siddiqui ZR, Jhingran R, Bains VK, Srivastava R, Madan R, Rizvi I. Comparative evaluation of platelet-rich fibrin versus beta-tri-calcium phosphate in the treatment of Grade II mandibular furcation defects using cone-beam computed tomography. Eur J Dent 2016;10(4):496-506

46 Dohan Ehrenfest DM, Piattelli A, Sammartino G, Wang HL. New biomaterials and regenerative medicine strategies in periodontology, oral surgery, esthetic and implant dentistry 2016. BioMed Res Int 2017;2017:8209507

47 Dohan Ehrenfest DM, Pinto NR, Pereda A, et al. The impact of the centrifuge characteristics and centrifugation protocols on the cells, growth factors, and fibrin architecture of a leukocyte- and platelet-rich fibrin (L-PRF) clot and membrane. Platelets 2018;29(2):171-184 